\title{
An Evening with Scotty Cameron
}

Being the occasion on which his friends have foregathered to express their regard for this warm and gracious man whose unending concern for books and learning has made him a true companion of scholars and a lasting inspiration for scholarship.

\section{DONALD F. CAMERON}

Bachelor of Science, Union College Master of Arts, Princeton University Doctor of Letters, Rutgers University Member of the English Faculty since 1929 University Librarian and Professor of English, Rutgers University Co-Founder, Rutgers University Press Organizer, Rutgers Research Council Honorary Member, Phi Beta Kappa Charter Member, Rutgers Press Council Honorary Member, Rutgers Classes of 1933 and 1956

Trustee, Nu Beta Chapter, Phi Gamma Delta

Enthusiast for all things Scottish (Whiskey and golf not excluded), sportsman, bibliophile, bon vivant.

The Rutgers University Commons Thursday, June 2, I 966 


\section{Menu}

CRAB CLAW COCKTAIL

CELERY, OLIVES, RADISHES

PRIME RIBS OF BEEF

BAKED POTATO WITH SOUR CREAM

BUTTERED PEAS WITH MUSHROOMS

TOSSED SALAD

ROLLS AND BUTTER

GREME DE MENTHE PAREAIT

COFFEE 


\section{Program}

Dr. MASON W. Gross ............ Master of Ceremonies

Dr. Peter Charanis

Hon. Phillip Forman

Dennis Sullivan

EDWARD LipMaN

I. RoBert KRIENDLER

Dr. Donald Forrester Cameron 